\title{
Effect of Different Breeding Densities and Inclusion of Soybean Oil on Performance, Carcass Trait and Heat Loss in Meat Quails
}

\author{
L. R. De Lima ${ }^{1}$, J. A. D. Barbosa Filho ${ }^{1}$, E. R. Freitas², D. H. Souza², V. S. S. Viana ${ }^{3}$, N. A. F. Machado \\ \& R. C. Nepomuceno ${ }^{2}$ \\ ${ }^{1}$ Department of Agricultural Engineering, Universidade Federal do Ceará, Fortaleza, Brazil \\ ${ }^{2}$ Department of Animal Science, Universidade Federal do Ceará, Fortaleza, Brazil. \\ ${ }^{3}$ Department of Animal Science, Universidade Federal de Viçosa, Viçosa, Brazil \\ Correspondence: L. R. De Lima, Center of Agricultural Sciences, Department of Agricultural Engineering, \\ Universidade Federal do Ceará, Bloco 804, Pici, Fortaleza, Brazil. Tel: 55-853-366-9756. E-mail: \\ luanda_rego@hotmail.com
}

Received: March 2, 2019

doi:10.5539/jas.v11n7p130
Accepted: April 3, $2019 \quad$ Online Published: May 31, 2019

URL: https://doi.org/10.5539/jas.v11n7p130

\begin{abstract}
Quails are homeothermic animals, in countries with a tropical climate, such as Brazil, birds face great difficulties in controlling body temperature inside the sheds. Several practices are being studied in order to keep these animals within the thermal comfort zone, and thus, to minimize the effects of thermal stress, partial substitution of carbohydrates by oils and changes in density are some of them. The objective of this study was to evaluate the different breeding densities and inclusion levels of soybean oil in performance, carcass characteristics and heat loss in quail. 450 quails, seven days old, distributed in a completely randomized design in a $3 \times 2$ factorial scheme, two densities $\left(215.6 \mathrm{~cm}^{2}\right.$ bird $^{-1}$ and $188.6 \mathrm{~cm}^{2}$ bird $\left.^{-1}\right)$ and three inclusion levels of soybean oil $(0,2,4 \%)$ were used, totaling six treatments with five replicates each. The heat loss by radiation was estimated with the aid of infrared thermography. The results showed that there was an effect of the density on feed consumption, which was lower for birds raised in the density of $188.6 \mathrm{~cm}^{2} \operatorname{bird}^{-1}$ (783.78 $\mathrm{g}$ of feed), but without its effect on weight gain and food conversion. No effect of inclusion levels of soybean oil was observed on any performance variables. There was no statistical difference $(\mathrm{P}>0.05)$ between treatments for any variables of carcass yield and parts, and heat loss by radiation analyzed. Therefore, it is concluded that soybean oil inclusion levels do not affect the performance and yield of quails, nor do they influence the loss of heat throughout the life cycle of these animals. The birds raised in the density of $188.6 \mathrm{~cm}^{2}$ bird $^{-1}$ obtained the lowest average dietary intake, with no impact on weight gain and feed conversion, allowing the creation of a greater number of birds per box.
\end{abstract}

Keywords: ambience, birds, Coturnix coturnix japonica, lipid sources

\section{Introduction}

In the last years, coturniculture has presented a very high development, adapted to the new techniques and production technologies, in which a subsistence activity starts to occupy a highly technified activity scenario (Pastore et al., 2012). According to the Instituto Brasileiro de Geografia e Estatística (IBGE, 2014), the effective quail in 2014 had an increase of $11.9 \%$ compared to that found in 2013, going from 18.2 to 20.3 million heads.

Some elements such as management, sanity, genetics, nutrition and ambience are pointed out as the support structure of poultry farming as an economic activity and indispensable in the production of affordable foods of high nutritional quality. However, in order to be successful, it is necessary to adopt new management practices, in order to prioritize animal welfare.

The greater heat tolerance is related to physiological particularities and adaptability of farm animals (Habibu et al., 2016), the higher heat tolerance, the greater the possibility of achieving the most productive index, since the maintenance of body temperature outside the thermal comfort zone requires energy expenditure, due to the physiological and behavioral effects performed to ensure the survival of the animals (Marques et al., 2018; Machado et al., 2019). Several strategies can be used to minimize the thermal discomfort of these animals, one of them is the use of foods in the diet that offer energy with low caloric increment, that is, diets in which the amount of oil of the rations is modified (Menten \& Pedroso, 2001; Machado et al., 2018). 
Several lipid sources are used in poultry feed, especially vegetable oils, which are sources rich in essential fatty acids. The partial substitution of carbohydrates by oil is based on the reduction of the caloric increment of the feed through the use of lipids as energy source. Thus, diets with higher lipid content may cause lower heat production by birds. Among the oils most used for this purpose is the soybean oil that is rich in phospholipids which are a special group of essential lipids in the use of fats by the animal organism.

According to Leandro et al. (2005), there is great pressure to reduce production costs, and to meet this requirement one of the alternatives being used is the increase in bird population density, this strategy may be a good option to increase the productive yield of the stock. The adequacy of the stocking density of the animals guarantees the use of space in the sheds, contributes to the maximum performance of the birds and favors issues related to animal welfare. In this context, the objective of this study was to evaluate the effect of different soybean oil inclusion levels on the diet and different breeding densities on performance, carcass characteristics and heat loss in quail.

\section{Method}

\subsection{Location and Experimental Animals}

The experiment was carried out in the poultry sector of the Agricultural Science Center of the Federal University of Ceará (UFC), Campus do Pici, located in the city of Fortaleza-CE, latitude ( $\left.3^{\circ} 44^{\prime} \mathrm{S}\right)$, longitude $\left(38^{\circ} 34^{\prime} \mathrm{W}\right)$ and altitude (19.6 m), with climatic classification, according to Köppen (1936) of Aw', defined as tropical rainy. The study was carried out between November 19/2016 to December 30/2016, with a duration of 42 days. A total of 450 quails, seven days old, were housed in a conventional shed for quail rearing divided into 30 boxes of $0.6 \times$ $0.6 \times 0.6 \mathrm{~m}$ (length $\times$ width $\times$ height), covered by nylon, with floor covered by bed, each box equipped with a tubular type feeder and a drinker type glass pressure.

\subsection{Experimental Design and Treatments}

The birds were distributed in a Completely Randomized Design (CRD) in a $3 \times 2$ factorial scheme, counting six treatments with five replicates each. The factors were three inclusion levels of soybean oil: $0,2,4 \%$ and two breeding densities: 14 birds/box $\left(215.6 \mathrm{~cm}^{2}\right.$ bird $\left.^{-1}\right)$ and 16 birds $\left(188.6 \mathrm{~cm}^{2}\right.$ bird $\left.^{-1}\right)$. The experimental rations (Table 1) were formulated according to the composition of the ingredients presented by Rostagno et al. (2011) and considering nutritional requirements for quails as recommended by Silva and Costa (2009), so that the rations were isoenergetic and isoproteic. In this way, the treatments were divided as follows: $\mathrm{T} 1=$ Reference Ration + density 14 quails; T2 = Reference feed + density 16 quails; T3 = Inclusion of $2 \%$ soybean oil + density 14 quails; T4 = Inclusion of $2 \%$ soybean oil + density 16 quails; T5 = Inclusion of $4 \%$ soybean oil + density 14 quails; $\mathrm{T} 6=$ Inclusion of $4 \%$ soybean oil + density 16 quails.

\subsection{Procedures and Variables Analyzed}

In order to evaluate the performance, the following variables were measured: - Feed consumption ( $\mathrm{g} / \mathrm{bird})$ : the feed provided at the beginning of the breeding phases and the leftovers at the end of the stages were weighed and, by difference, the feed intake was calculated for each repetition; Weight gain ( $\mathrm{g} / \mathrm{bird})$ : the birds of each replicate were weighed on the 7th day and 42nd day so that the average weight gain of each plot was calculated by the difference of the final weight minus the initial weight; Food conversion: it was calculated by dividing the feed intake by the weight gain of the birds. Throughout the experimental period ration and water were provided at will, mortality was recorded for correction of feed intake and, consequently, feed conversion (Sakomura \& Rostagno, 2007).

To evaluate the carcass characteristics, at 42 days of age two birds from each experimental unit, one male and one female, were selected based on the average weight of the plot and submitted to a 6-hour fasting. After this period the birds were weighed, desensitized, bled, scalded, plucked, eviscerated and removed from the head, neck and feet to determine the carcass yield in relation to the body weight of the fasting bird. Subsequently, the carcasses were cut and the parts weighed to determine the yield of breast, thigh + overcoat and percentage of abdominal fat, which were calculated in relation to the weight of the warm carcass, and liver that was calculated in relation to the weight of the fasting bird.

In order to obtain air temperature (Ta) and relative air humidity (UF), Meteorological Minidimensions and Data logger (onset ${ }^{\circledR}$ Mark, model U23-001 HOBO ${ }^{\circledR}$ Pro v2) were positioned, positioned at the height of the quails, inside the boxes in that they were during the whole experimental phase. For this purpose, this equipment was previously programmed to record the values of air temperature $\left(\mathrm{Ta},{ }^{\circ} \mathrm{C}\right)$ and relative air humidity $(\mathrm{RH}, \%)$ at 10 minute intervals, from the 1 st to the 42 nd day of life of the quails. Three Data loggers were installed throughout the shed, one at the beginning, the middle and the other at the end of the shed. 
To obtain the body surface temperature $\left(\mathrm{Ts},{ }^{\circ} \mathrm{C}\right)$ of the quails an infrared thermographic camera was used (Flir Systems brand, model Flir i3, resolution $60 \times 60$ pixels, precision $+/-2 \%$ or $\left.2{ }^{\circ} \mathrm{C}\right)$. Three individual thermograms were performed per plot at 42 days of life of the quails, one meter away from the animals, according to the manufacturer's recommendation. An emissivity of 0.98 was considered, which is indicated by the manufacturer for biological tissues. Later, these thermographic images were analyzed by the software Flir QuickReport $($ 1.2, to obtain the average surface temperature of the entire body surface of the birds.

Table 1. Composition of the experimental rations used

\begin{tabular}{|c|c|c|c|}
\hline \multirow{2}{*}{ Ingredients } & \multicolumn{3}{|c|}{ Levels of soybean oil (\%) } \\
\hline & 0 & 2 & 4 \\
\hline Corn & 55.89 & 49.93 & 43.93 \\
\hline Soybean meal & 40.03 & 41.80 & 43.93 \\
\hline Soy oil & 0.00 & 2.00 & 4.00 \\
\hline Corn gluten meal $60 \%$ & 0.55 & 0.00 & 0.00 \\
\hline Limestone & 1.10 & 1.09 & 1.09 \\
\hline Dicalcium phosphate & 0.91 & 0.91 & 0.92 \\
\hline Common salt & 0.35 & 0.36 & 0.36 \\
\hline DL-Methionine & 0.27 & 0.28 & 0.28 \\
\hline Min+vit ${ }^{1}$ supplement & 0.20 & 0.20 & 0.20 \\
\hline Salinomycin & 0.05 & 0.05 & 0.05 \\
\hline Inert & 0.65 & 3.39 & 6.33 \\
\hline Total & 100 & 100 & 100 \\
\hline \multicolumn{4}{|l|}{ Calculated Nutritional Level } \\
\hline Metabolizable energy (Kcal/Kg) & 2.950 & 2.950 & 2.950 \\
\hline Gross Protein $\%$ & 23.00 & 23.00 & 23.00 \\
\hline Fat $\%$ & 2.73 & 4.52 & 6.31 \\
\hline Calcium $\%$ & 0.75 & 0.75 & 0.75 \\
\hline Avaiable phosphorus $\%$ & 0.29 & 0.29 & 0.29 \\
\hline Lysine digestible $\%$ & 1.14 & 1.17 & 1.18 \\
\hline Methionine + Cystine digestible $\%$ & 0.89 & 0.89 & 0.89 \\
\hline Digestible methionine $\%$ & 0.57 & 0.58 & 0.58 \\
\hline Sodium $\%$ & 0.16 & 0.16 & 0.16 \\
\hline Chlorine\% & 0.27 & 0.26 & 0.26 \\
\hline Potassium $\%$ & 0.90 & 0.91 & 0.91 \\
\hline Threonine $\%$ & 0.79 & 0.79 & 0.79 \\
\hline
\end{tabular}

Note. ${ }^{1}$ Guarantee levels per kg of product: Vitamin A 5.500.000 UI, Vitamin B1 $500 \mathrm{mg}$, Vitamin B12 7.500 mcg, Vitamin B2 $2.502 \mathrm{mg}$, Vitamin B6 $750 \mathrm{mg}$, Vitamin D3 1.000.000 UI, Vitamin E 6.500 UI, Vitamin K3 $1.250 \mathrm{mg}$, Biotin $25 \mathrm{mg}$, Niacin $17.5 \mathrm{~g}$, Folic Acid $251 \mathrm{mg}$, Pantothenic acid $6.030 \mathrm{mg}$, Cobalt $50 \mathrm{mg}$, Copper $3.000 \mathrm{mg}$, Iron $25 \mathrm{~g}$, Iodine $500 \mathrm{mg}$, Manganese $32.5 \mathrm{~g}$, Selenium $100.05 \mathrm{mg}$, Zinc $22.49 \mathrm{~g}$. ${ }^{2}$ Inert: Sand washed.

For the calculation of the individual mean surface temperature (Ts) of the animals, 30 random points were marked along the whole body surface of the birds in thermographic images. The loss of sensible heat was considered as the loss of heat by radiation. The surface area calculation was performed using Equation 1 (Curtis, 1983; Silva, 2000). Thus, the surface in $0.151 \mathrm{~m}^{2}$. From this data the estimation of heat loss by radiation (Qs = Qr) was carried out to measure the amount of heat loss from birds to the environment. Qr was calculated using Equation 2 (Meijerhof \& Van Beek, 1993; Yahav et al., 2004).

$$
A=m \cdot w b
$$

Where, $\mathrm{A}=$ area of the animal's body surface $\left(\mathrm{m}^{2}\right) ; \mathrm{m}=$ mech constant $(0.100) ; \mathrm{w}=$ body weight of the animal $(\mathrm{g}) ; \mathrm{b}=$ constant $(0.607)$.

$$
Q r=\varepsilon \sigma A \cdot\left(T s^{4}-T a^{4}\right)
$$

Where, $\mathrm{Qr}=$ loss of heat by radiation (W); $\varepsilon=$ emissivity of biological tissue; $\sigma=$ Stefan Boltzmann constant $\left(5.6710^{-8} \mathrm{~W} \mathrm{~m}^{-2} \mathrm{~K}^{-4}\right)$; $\mathrm{A}=$ surface area of the bird $\left(\mathrm{m}^{2}\right)$; Ts = bird's surface temperature $\left({ }^{\circ} \mathrm{C}\right)$ and $\mathrm{Ta}=$ air temperature $\left({ }^{\circ} \mathrm{C}\right)$. Note: temperatures were converted to Kelvin $\left({ }^{\circ} \mathrm{K}\right)$ for calculation of heat loss. 


\subsection{Statistic}

For statistical analysis of performance and carcass yield, parts and heat loss, the data were submitted to analysis of variance and the means compared by the SNK test at 5\% significance, using the program "Statistical Analyzes System" (SAS, 2000)

\section{Results and Discussion}

\subsection{Performance}

During the experiment the minimum and maximum averages recorded inside the shed were $30.3{ }^{\circ} \mathrm{C}$ and $33{ }^{\circ} \mathrm{C}$ for air temperature and $58.2 \%$ and $72.3 \%$ for relative humidity, respectively. The performance data for cutting quails, from 7 to 42 days of age, submitted to diets with different levels of soybean oil and breeding densities are described in Table 2.

In the analysis of variance, it was verified that there was no significant interaction among the factors, soybean oil levels and breeding densities, on feed intake (CR), weight gain (GP) and feed conversion evaluation period. It was also possible to observe that diets did not significantly influence these variables during the study. However, there was a difference between rearing densities over feed consumption, but the same was not observed for the other variables (GP and CA).

Considering that the inclusion of the energy level has been studied as the main factor that influences the voluntary consumption of feed by the birds (Freitas et al., 2011), it can be inferred that the lack of significant effect of the inclusion of soybean meal on feed consumption may be associated with a good evaluation of the metabolizable energy value of the food, considering that the rations were calculated to be isoenergetic considering the values of metabolizable energy of soybean oil determined for the quails during the period studied.

Table 2. Performance of cutting quails fed different levels of soybean oil in the diet and rearing densities in the period from 7 to 42 days of age

\begin{tabular}{|c|c|c|c|c|c|c|c|c|}
\hline \multirow{2}{*}{ Density of creation (D) } & \multicolumn{3}{|c|}{ Oil level (N) } & \multirow{2}{*}{ Mean } & \multirow{2}{*}{$\mathrm{CV}^{1}(\%)$} & \multicolumn{3}{|c|}{ Effect } \\
\hline & $0.0 \%$ & $2.0 \%$ & $4.0 \%$ & & & $\mathrm{~N}$ & $\mathrm{D}$ & $\mathrm{N} \times \mathrm{D}$ \\
\hline \multicolumn{9}{|l|}{ Feed intake (g/bird) } \\
\hline $215.6 \mathrm{~cm}^{2}$ bird $^{-1}$ & 809.51 & 817.60 & 798.97 & $808.69^{a}$ & & & & \\
\hline $188.6 \mathrm{~cm}^{2}$ bird $^{-1}$ & 779.55 & 782.60 & 789.18 & $783.78^{\mathrm{b}}$ & 3.91 & 0.8910 & 0.0384 & 0.6378 \\
\hline Mean & 794.53 & 800.10 & 794.08 & & & & & \\
\hline \multicolumn{9}{|l|}{ Weight gain (g/bird) } \\
\hline $215.6 \mathrm{~cm}^{2}$ bird $^{-1}$ & 221.89 & 222.17 & 225.04 & 223.03 & & & & \\
\hline $188.6 \mathrm{~cm}^{2}$ bird $^{-1}$ & 218.20 & 223.60 & 222.08 & 221.29 & 2.97 & 0.4601 & 0.4767 & 0.6483 \\
\hline Mean & 220.05 & 222.89 & 223.56 & & & & & \\
\hline \multicolumn{9}{|l|}{ Food conversion } \\
\hline $215.6 \mathrm{~cm}^{2}$ bird $^{-1}$ & 3.65 & 3.60 & 3.56 & 3.60 & & & & \\
\hline $188.6 \mathrm{~cm}^{2}$ bird $^{-1}$ & 3.57 & 3.57 & 3.58 & 3.57 & 3.41 & 0.7302 & 0.5270 & 0.6950 \\
\hline Mean & 3.61 & 3.58 & 3.57 & & & & & \\
\hline
\end{tabular}

Note. ${ }^{1} \mathrm{CV}=$ coefficient of variation. Means followed by the same lowercase letters in the columns do not differ statistically from one another by the SNK test $(\mathrm{P}<0.05)$.

For the feed intake variable, it was possible to observe that there was a significant difference at $5 \%$ of significance for the different breeding densities used in this experiment. The data show that a lower consumption $(783.78 \mathrm{~g} / \mathrm{bird})$ occurred in the highest density of animals $\left(188.6 \mathrm{~cm}^{2}\right.$ bird $\left.^{-1}\right)$. According to Goldflus et al. (1997), the gradual increase in the rates of densification during the rearing period reduces the feed intake of the animals. Lima et al. (2012) report that high housing densities can cause competition among birds for food, which can affect consumption and decrease feed intake by animals.

As for the variable weight gain, the results obtained in this research for quails, resemble those found by Vieira et al. (2002), who did not observe a significant difference $(P>0.05)$ in the weight gain of broiler chickens reared from 8 to 42 days old, consuming rations containing soybean oil of 2 and $4 \%$ concentrations. Lana et al. (2001) studied the effect of density and feeding programs on the performance of broiler chickens, in which it was 
possible to verify worsening of feed conversion of these birds with increasing density, this fact differs from the results found in this study, since there was no significant difference for this variable.

The results for the effect of density on weight gain obtained in this research do not agree with those described by Moreira et al. $(\mathrm{P}<0.05)$. The results of this study show that the effect of the population density on performance, carcass yield and meat quality in broiler chickens of different commercial strains, observed that the densities influenced weight gain $(\mathrm{P}<0.05)$; in which the birds raised in the density of $10 \mathrm{birds} / \mathrm{m}^{2}$ presented better gain than those created in the densities of 13 and $16 \mathrm{birds} / \mathrm{m}^{2}$.

\subsection{Carcass Characteristics}

Data on the percentage of carcass traits, noble cuts, abdominal fat and liver for meat quails, slaughtered at 42 days of age, submitted to diets with different levels of soybean oil and rearing densities are described in Table 3 . For the carcass characteristics, it was observed that there was no significant interaction between the factors, levels of soybean oil and breeding densities, on any of the evaluated variables. It was also observed that the treatments did not significantly influence the carcass characteristics evaluated.

Table 3. Carcass characteristics of meat quails, at 42 days of age, fed with different levels of soybean oil in the ration and rearing densities

\begin{tabular}{|c|c|c|c|c|c|c|c|c|}
\hline \multirow{2}{*}{ Density of creation (D) } & \multicolumn{3}{|c|}{ Oil level (N) } & \multirow{2}{*}{ Mean } & \multirow{2}{*}{ CV (\%) } & \multicolumn{3}{|c|}{ Effect } \\
\hline & $0.0 \%$ & $2.0 \%$ & $4.0 \%$ & & & $\mathrm{~N}$ & $\mathrm{D}$ & $\mathrm{N} \times \mathrm{D}$ \\
\hline \multicolumn{9}{|l|}{ Carcass yield (\%) } \\
\hline $215.6 \mathrm{~cm}^{2}$ bird $^{-1}$ & 75.10 & 75.21 & 74.23 & 74.85 & \multirow{3}{*}{3.56} & \multirow{3}{*}{0.8231} & \multirow{3}{*}{0.9378} & \multirow{3}{*}{0.7518} \\
\hline $188.6 \mathrm{~cm}^{2}$ bird $^{-1}$ & 75.11 & 74.65 & 74.94 & 74.90 & & & & \\
\hline Mean & 75.10 & 74.93 & 74.58 & & & & & \\
\hline \multicolumn{9}{|l|}{ Chest yield (\%) } \\
\hline $215.6 \mathrm{~cm}^{2}$ bird $^{-1}$ & 43.23 & 43.62 & 43.41 & 43.42 & & & & \\
\hline $188.6 \mathrm{~cm}^{2}$ bird $^{-1}$ & 43.77 & 42.82 & 42.68 & 43.09 & 3.07 & 0.5496 & 0.3423 & 0.2106 \\
\hline Mean & 43.50 & 43.22 & 43.05 & & & & & \\
\hline \multicolumn{9}{|l|}{ Thigh + overcoat yield (\%) } \\
\hline $215.6 \mathrm{~cm}^{2}$ bird $^{-1}$ & 24.94 & 24.08 & 24.39 & 24.47 & & & & \\
\hline $188.6 \mathrm{~cm}^{2}$ bird $^{-1}$ & 24.60 & 23.91 & 24.47 & 24.33 & 4.31 & 0.0747 & 0.5964 & 0.8193 \\
\hline Mean & 24.77 & 24.00 & 24.43 & & & & & \\
\hline \multicolumn{9}{|l|}{ Abdominal fat (\%) } \\
\hline $215.6 \mathrm{~cm}^{2}$ bird $^{-1}$ & 1.49 & 1.33 & 1.57 & 1.46 & & & & \\
\hline $188.6 \mathrm{~cm}^{2}$ bird $^{-1}$ & 1.43 & 1.54 & 1.60 & 1.52 & 22.40 & 0.3794 & 0.5289 & 0.4224 \\
\hline Mean & 1.46 & 1.44 & 1.58 & & & & & \\
\hline \multicolumn{9}{|l|}{ Liver (\%) } \\
\hline $215.6 \mathrm{~cm}^{2}$ bird $^{-1}$ & 2.55 & 2.29 & 2.45 & 2.43 & & & & \\
\hline $188.6 \mathrm{~cm}^{2} \mathrm{bird}^{-1}$ & 2.48 & 2.45 & 2.16 & 2.36 & 25.19 & 0.5383 & 0.6336 & 0.5127 \\
\hline Mean & 2.51 & 2.37 & 2.30 & & & & & \\
\hline
\end{tabular}

Note. ${ }^{1} \mathrm{CV}=$ coefficient of variation. Means followed by the same lowercase letters in the columns do not differ statistically from one another by the SNK test $(\mathrm{P}<0.05)$.

According to Freitas et al. (2006), when the nutritional value of the food is well evaluated, the probability that the carcass characteristics are influenced by the inclusion of that food in the isonutrientes diets becomes very unlikely. However, if the metabolizable energy value of the food is disregarded, its inclusion in the diet may cause alterations in the energy: protein ratio of the feed, and thus, cause changes in carcass yield and even carcass cuts. Therefore, it can be deduced that increased soybean oil levels in the diet were not sufficient to alter the energy: protein correlation of the diet to the point of causing significant variation on carcass characteristics and parts of quail observed in this study. According to the literature the carcass yield of quails can range from 57 to 74\% (Móri et al., 2005; Oliveira et al., 2005; Santos et al., 2006; Silva et al., 2007; Corrêa et al., 2008), the values found in this study were similar to the maximum value described above by the authors.

The results obtained by Lara et al. (2006) according to these authors, the lipid sources of plant origin do not influence the carcass yield, viscera and cuts (chest and thigh) or the percentage of abdominal fat. According to Oliveira Neto et al. (2000), who evaluated the effect of ambient temperature on performance and carcass 
characteristics of broilers fed a controlled diet and two levels of metabolizable energy, observed a decrease in carcass, breast and liver yield of broiler chickens as the feed oil level increased. These results differed from those found in the present study.

As for the percentage of abdominal fat, the results obtained for quails in this research differed from those found by Meza et al. (2015). According to these authors, the levels of metabolizable energy and digestible lysine on the composition and carcass yield of broilers, it was observed that the values of abdominal fat increase proportional to the increase of energy level in the diet. This difference in results can be explained by Café (2001), where it is stated that manual removal of abdominal fat from the carcass causes significant variation in the values, causing high coefficients of variation and decreasing the sensitivity of the statistical test to detect significant differences.

The data obtained in this research are similar to those reported for broiler chickens by Moreira et al. (2004), where the effect of the population density, 10 to $16 \mathrm{birds} / \mathrm{m}^{2}$, on yield of different commercial strains, did not observe a significant difference $(\mathrm{P}>0.05)$ for any variable with the elevation of breeding density. As well as the results found by Goldflus et al. (1997), in which studying the effects of population density and diet energy on the performance of broiler chickens also noticed that when varying the densities of 10 to $22 \mathrm{birds} / \mathrm{m}^{2}$, no differences were observed for carcass yield.

\subsection{Heat Loss}

Table 4 shows the values of Qr, loss of heat sensitive by radiation, between treatments and during the 2nd, 3rd, 4th, 5th and 6th week of life of the quails. As shown in Table 4, it can be observed that there was no significant difference for the Qr variable in any evaluated week. It is suggested, then, that the oil inclusion levels and the different densities did not influence to increase or decrease the radiation heat loss in the birds.

According to Lehninger (2002), in general, oils and fats with the highest number of unsaturated bonds in their structure, such as soybean oil, tend to present higher metabolic heat production from their break, this fact was not observed in this study, since there was no difference in relation to the different concentrations of soybean oil in the diet. A fact to be mentioned regarding the explanation of not obtaining significant difference for heat loss from the addition of the different levels of soybean oil, can be attributed to the presence of feathers in the birds, they play an important role in the thermal balance between the organism and the environment, implying peculiarities in the regulation of thermal equilibrium.

According to Malheiros et al. (2000), the feathers directly interfere in the loss of heat by radiation, conduction and radiation as a mechanism of elimination of heat and considering tropical climate locations the temperature differential between the environment and the body surface of the animals is small. According to Nascimento (2010) when the air temperature is at levels close to $21^{\circ} \mathrm{C}$, the bird can lose up to $75 \%$ of heat through sensible heat: radiation, conduction and convection.

However, when the ambient temperature approaches the surface temperature of the birds, its main means of heat loss becomes the release of latent heat through panting. Souza Júnior et al. (2013) mentioned that birds' feathers have good insulating properties, blocking most of the infrared emission from the skin and the use of thermography is a good tool to perform the thermal mapping. These same authors have mapped the temperature of Japanese quails using infrared thermography and concluded that these birds present differences in the surface temperature according to the body region, and the areas without feathers are considered important sites of thermolysis, area favorable to heat loss, under heat stress conditions. 
Table 4. Radiation heat loss means $(\mathrm{Qr} / \mathrm{W})$ of meat quails in the $2^{\text {nd }}, 3^{\text {rd }}, 4^{\text {th }}, 5^{\text {th }}$ and $6^{\text {th }}$ week of life, fed with different levels of soybean oil in the feed and rearing densities

\begin{tabular}{|c|c|c|c|c|c|c|c|c|c|}
\hline \multirow{2}{*}{ Weeks } & \multirow{2}{*}{$\begin{array}{l}\text { Density } \\
\left(\mathrm{cm}^{2} \text { bird }^{-1}\right)\end{array}$} & \multicolumn{3}{|c|}{ Oil level (\%) } & \multirow{2}{*}{ Mean Qr } & \multirow{2}{*}{ CV (\%) } & \multicolumn{3}{|c|}{ Value of $\mathrm{P}$} \\
\hline & & 0 & 2 & 4 & & & $\mathrm{~N}$ & $\mathrm{D}$ & $\mathrm{O} \times \mathrm{D}$ \\
\hline \multirow{3}{*}{$2^{\text {nd }}$} & 215.6 & 5.65 & 6.14 & 5.90 & 5.90 & & & & \\
\hline & 188.6 & 5.93 & 6.16 & 6.13 & 6.07 & 16.01 & 0.706 & 0.613 & 0.951 \\
\hline & Mean & 5.79 & 6.15 & 6.02 & & & & & \\
\hline & 215.6 & 4.58 & 4.99 & 4.56 & 4.71 & & & & \\
\hline \multirow[t]{2}{*}{$3^{\text {rd }}$} & 188.6 & 4.59 & 4.81 & 4.60 & 4.66 & 11.88 & 0.344 & 0.831 & 0.891 \\
\hline & Mean & 4.59 & 4.90 & 4.58 & & & & & \\
\hline \multirow{3}{*}{$4^{\text {th }}$} & 215.6 & 3.98 & 3.84 & 3.72 & 3.85 & & & & \\
\hline & 188.6 & 3.94 & 3.96 & 3.93 & 3.94 & 10.30 & 0.752 & 0.539 & 0.787 \\
\hline & Mean & 3.96 & 3.90 & 3.83 & & & & & \\
\hline \multirow{3}{*}{$5^{\text {th }}$} & 215.6 & 3.50 & 3.28 & 2.96 & 3.25 & & & & \\
\hline & 188.6 & 3.37 & 3.36 & 3.28 & 3.34 & 18.30 & 0.502 & 0.708 & 0.704 \\
\hline & Mean & 3.44 & 3.32 & 3.12 & & & & & \\
\hline \multirow{3}{*}{$6^{\text {th }}$} & 215.6 & 2.97 & 3.25 & 3.00 & 3.07 & & & & \\
\hline & 188.6 & 3.13 & 3.21 & 2.87 & 3.07 & 15.28 & 0.387 & 0.942 & 0.783 \\
\hline & Mean & 3.05 & 3.23 & 2.94 & & & & & \\
\hline \multirow{3}{*}{ Total } & 215.6 & 4.14 & 4.30 & 4.03 & 4.16 & & & & \\
\hline & 188.6 & 4.19 & 4.30 & 4.16 & 4.22 & 8.67 & 0.447 & 0.657 & 0.923 \\
\hline & Mean & 4.17 & 4.30 & 4.10 & & & & & \\
\hline
\end{tabular}

Note. Means followed by equal letters, uppercase in the column and lowercase in the row, do not differ from each other by the SNK test $(\mathrm{P}<0.05)$.

\section{Conclusion}

Up to $4 \%$ levels of soybean oil can be included in the feed and use rearing densities of $215.6 \mathrm{~cm}^{2}$ bird $^{-1}$ and $188.6 \mathrm{~cm}^{2}$ bird $^{-1}$ without affecting the performance, carcass characteristics and heat loss by radiation of meat quails from 7 to 42 days of age.

\section{References}

Brandão, T. M. (2008). Different types of soybean oils and energy levels in chicken diets: Performance and carcass characteristics (p. 62). (Dissertação. Universidade Federal do Piauí, Teresina, Brasil). Retrieved from http://livros01.livrosgratis.com.br/cp138104.pdf

Café, M. B. (2001). Influence of different methionine and lysine levels on performance and carcass characteristics of broiler chickens (p. 68). (Universidade Estadual Paulista, Jaboticabal, Brazil). Retrieved from https://www.avisite.com.br/index.php?page=cet\&subpage=trabalhostecnicos\&id $=38$

Campos, S. S. (1999). Effects of dietary energy, population density, bed height and time of year on thermoregulatory, zootechnical and bed parameters in broilers (p. 62, Universidade Estadual Paulista, Brasil). Retrieved from http://www.scielo.br/scielo.php?script=sci_nlinks\&ref=000117\&pid=S1516-359820 0400060001800004\&lng=en

Crespo, N., \& Esteve-Garcia, E. (2001). Dietary fatty acid profile modifies abdominal fat deposition in broiler chickens. Poultry Science, 80, 71-78. https://doi.org/10.1093/ps/80.1.71

Curtis, S. E. (1983). Environmental management in animal agriculture (p. 409). Ames: State University Press.

Corrêa, G. S. S., Silva, M. A., Corrêa, A. B., Fontes, D. O., Santos, G. G., \& Lima Neto, H. R. (2008). Crude protein level for quail during the growth period. Brazilian Archives of Veterinary Medicine and Zootechnics, 60(1), 209-217.

Cobb Vantress Brasil. (2008). Manual de manejo de frangos de corte (p. 66). Guapiaçu: Cobb Vantres. Retrieved from https://wp.ufpel.edu.br/avicultura/files/2012/04/Cobb-Manual-Frango-Corte-BR.pdf

Freitas, E. R., Fuentes, M. F. F., Júnior, A. S., Guerreiro, M. E. G., \& Espíndula, G. B. (2006). Cashew nut meal in broiler chicken diets. Brazilian Agricultural Research, 41(6), 1001-1006. 
Freitas, E. R., Lima, R. C., Silva, R. B., Sucupira, F. S., Moreira, R. F., \& Lopes, V. B. R. (2011). Replacement of soybean meal by coconut meal in rations containing cashew nuts for broilers. Brazilian Journal of Animal Science, 40(5), 1006-1013.

Goldflus, F., ArikI, J., Kronka, S. N., Sakomura, N. K., \& De Moraes, V. M. B. (1997). Effects of dietary density and energy on the performance of broiler chickens. Brazilian Journal of Animal Science, 26(2), 310-315.

Gonzalo, G. M. (1982). Rate of passage (transit time) as influenced by level of supplemental fat. Poultry Science, 61, 94-100. https://doi.org/10.3382/ps.0610094

Hurwitz, S., Plavnik, I., Ben-Gal, I, \& Bartov, I. (1987). Response of growing turkeys to dietary fat. Poultry Science, 66, 2208-2217.

Habibu, B., Kawu, U. M., Makum, H. J., Aluwong, T., \& Yaqub, L. S. (2016). Seasonal variation in body mass index, cardinal physiological variables and serum thyroid hormones profiles in relation to susceptibility to thermal stress in goat kids. Small Ruminant Research, 145, 20-27. https://doi.org/10.1016/j.smallrumres. 2016.10.023

IBGE (Instituto Brasileiro De Geografia and Estatística). (2010). Produção da Pecuária Municipal. Brasil, Retrieved from https://downloads.ibge.gov.br/downloads_estatisticas.htm

Lana, G. R. Q., Silva Junior, R. G. C., Valerio, S. R., Lana, A. M. Q., \& Cordeiro, E. C. G. B. (2001). Effect of density and feeding programs on performance of broiler chickens. R. Bras. Zootec, 30(4), 1258-1265. https://doi.org/10.1590/S1516-35982001000500019

Lara, L. J. C., Baião, N. C., Aguilar, C. A. L., Cançados, S.V., Fiuza, M. A., \& Ribeiro, B. R. C. (2005). Effect of lipid sources on the performance of broiler chickens. Brazilian Archives of Veterinary Medicine and Zootechnics, 57(6), 792-798.

Leandro, N. S. M., Vieira, N. S., Matos, M. S., Café, M. B., Stringhini, J. H., \& Santos, D. A. (2005). Productive performance of Japanese quail (Coturnix coturnix japonica) submitted to different densities and types of deboning. Acta Scientiarum Animal Sciences, 27(1), 129-135.

Lehninger, A. L. (2002). Principles of Biochemistry (3rd ed.). São Paulo.

Machado, N. A. F., Barbosa-Filho, J. A. D., Oliveira, K. P. L., Parente, M. O. M., Siqueira, J. C., Pereira, A. M., ... Costa C. S. (2019). Biological rhythm of goats and sheep in response to heat stress. Biological Rhythm Research, 50, 1-9. https://doi.org/10.1080/09291016.2019.1573459

Machado, N. A. F., Parente, M. O. M., Parente, H. N., Zanine, A. M., Moreira Filho, M. A., Cunha, I. A. L., ... Araujo, J. S. (2018). The physiological response, feeding behaviour and water intake of feedlot lambs supplemented with babassu oil or buriti oil. Biological Rhythm Research, 49, 1-12. https://doi.org/10.1080/ 09291016.2018 .1526499

Malheiros, R. D., Moraes, V. M. B., Bruno. L. D. G., Malheiros, E. B., Furlan, R. L., \& Macari, M. (2000). Environmental temperature and cloacal and surface temperatures of broiler chicks in first week post-hatch. Journal of Applied Poultry Science, 9, 111-117. https://doi.org/10.1093/japr/9.1.111

Marques, J. I., Lopes-Neto, J. P., Nascimento, J. W. B., Talieri, I. C., Medeiros, G. R., \& Furtado, D. A. (2018). Pupillary dilation a termal stress indicator in boer crossbred goats maintained in a climate chamber. Small Ruminant Research, 158, 26-29. https://doi.org/10.1016/j.smallrumres.2017.11.013

Meijerhof, R., \& Van beek, G. (1993). Mathematical modeling of temperature and moisture of hatching eggs. Journal of Theoretical Biology, 65, 27-41. https://doi.org/10.1006/jtbi.1993.1175

Menten, J. F. M., \& Pedroso, A. A. (2001). Nutrition of birds in hot climates. In I. J. O. Silva (Ed.), Ambience in the production of birds in tropical climate (p. 200). Jaboticabal: FUNEP.

Meza, S. K. L., Nunes, R. V., Tsutsumi, C. Y., Vieites, F. M., Scherer, C., Henz, J. R., Silva, I. M., \& Bayerle, D. F. (2015). Levels of metabolizable energy and digestible lysine on the composition and carcass yield of broilers. Semina: Agrarian Sciences, 36(2), 1079-1089.

Moreira, J., Mendes, A. A., Roça, R. O., Garcia, E. A., Naas, I. A., Garcia, R. G., \& Paz, I. C. L. A. (2004). Effect of population density on performance, carcass yield and meat quality in broilers of different commercial strains. Brazilian Journal of Animal Science, 33(6), 1506-1519. 
Móri, C., Garcia, E. A., Pavan, A. C., Piccinin A., Scherer, M. R., \& Pizzolante, C. C. (2005). Performance and carcass yield of four genetic groups of quails for meat production. Brazilian Journal of Animal Science, 34(3), 870-876.

Nascimento, S. T., Silva, I .J. O. (2010). The heat losses of poultry: Understanding heat exchanges with the environment. Retrived from http://www.avisite.com.br/cet/img/20100 916_trocasdecalor.pdf

Oliveira, E. G., Almeida, M. I. M., Mendes, A. A., Veiga, N., Roça, R. O., \& Dias, K. (2005). Evaluation of carcass yield of meat quails fed diets with different protein levels. Archives of Veterinary Science, 10(3), $42-45$.

Oliveira Neto, A. N., Oliveira, R. F. M., Donzele, J. L. Rostagno H. S., Ferreira, R. A., Maximiano, H. C., \& Gasparino, E. (2000). Effect of Ambient Temperature on Performance and Carcass Characteristics of Broiler Chickens Fed with Controlled Diet and Two Levels of Metabolizable Energy. Brazilian Journal of Animal Science, 29(1), 183-190.

Rostagno, H. S., Albino, L. F. T., Donzele, J. L., Gomes, P. C., Oliveira, R. F., Lopes, D. C., ... Euclides, R. F. (2011). Brazilian tables for poultry and pigs: Food composition and nutritional requirements (3rd ed., p. 252). Viçosa, MG: Universidade Federal de Viçosa.

Sakomura, N. K., \& Rostagno, H. S. (2007). Research methods in monogastric nutrition (p. 283). Jaboticabal: Funep.

Santos, M. S. V., Espíndola, G. B., Lôbo, R. N. B., Fuentes, M. F. F., Carvalho, L. E., \& Santos, A. B. E. (2009). Performance and egg quality of commercial laying hens submitted to diets with different vegetable oils. Brazilian Journal of Animal Health and Production, 10(3), 654-667.

Santos, A. L. S., Gomes, A. V. C., Pessôa, M. F., Mostafá, S., Araújo, A. H. B., \& Vieira, A. A. (2006). Chemical composition and energetic values of protein sources in meat quails at different ages. Rural Science, 36(3), 930-935. https://doi.org/10.1590/S0103-84782006000300031

Souza Júnior, J. B. F., Queiroz, J. P. A. F., Domingos, H. G. T., Torquato, J. L.., Sá Filho, G. F., \& Costa, L.L.M. (2013). Thermographic evaluation of Japanese quails (Coturnix coturnix japonica). Journal of Animal Behaviour and Biometeorology, 1, 61-64.

SAS Institute. (2001). User's guide: Statistics, Version 8.0 edition. SAS Institute Inc, Cary, NC.

Silva, R. G. (2000). Introduction to animal bioclimatology. Funep, Jaboticabal.

Silva, J. H. V., \& Costa, F. G. P. (2009). Nutritional requirements for Japanese and European Quails (2nd, p. 84-107). Jaboticabal-SP: FUNEP.

Silva, J. H. V., Costa, F. G. P., \& Silva, E. L. (2007). Nutritional requirements for quails. Simposio Internacional de Coturnicultura (pp. 44-64). Lavras Anais.

Vieira, S. L., Ribeiro, A. M. L., Kessler, A. M., Fernandes, L. M., Ebert, A. R., \& Eichner, G. (2002). Utilization of Diets Energy for Broilers Formulated with Soybean Oil. Brazilian Journal of Poultry Science, 4(2)1-13. https://doi.org/10.1590/S1516-635X2002000200005

Yahav, S., Straschnow, A., Luger, D., Shinder, D., Tanny, J., \& Cohen, S. (2004). Ventilation, sensible heat loss, broiler energy, and water balance under harsh environmental conditions. Poultry Science, 83, 253-258. https://doi.org/10.1093/ps/83.2.253

\section{Copyrights}

Copyright for this article is retained by the author(s), with first publication rights granted to the journal.

This is an open-access article distributed under the terms and conditions of the Creative Commons Attribution license (http://creativecommons.org/licenses/by/4.0/). 